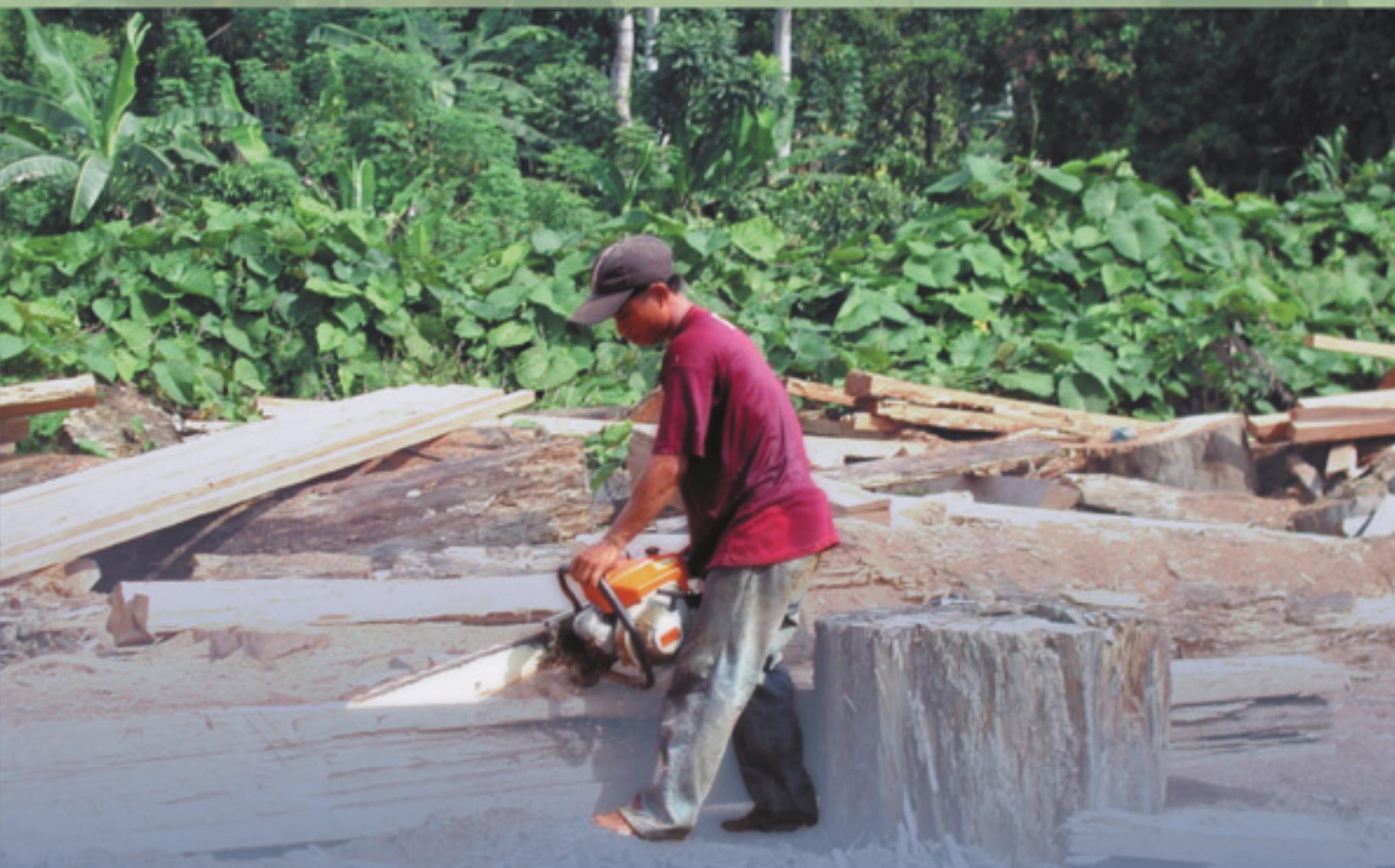

\title{
The role of collective action in determining the benefits from IPPK logging concessions: A case study from Sekatak, East Kalimantan
}




\section{The role of collective action in determining the benefits from IPPK logging concessions: A case study from Sekatak, East Kalimantan \\ Charles Palmer}

Governance Program

CIFOR Working Paper No. 28 
(C) 2004 by CIFOR

All rights reserved. Published in 2004

Cover photo by Budhy Kristanty

Published by

Center for International Forestry Research

Mailing address: P.O. Box 6596 JKPWB, Jakarta 10065, Indonesia

Office address: Jl. CIFOR, Situ Gede, Sindang Barang,

Bogor Barat 16680, Indonesia

Tel : +62 (251) 622622

Fax: +62 (251) 622100

E-mail: cifor@cgiar.org

Web site: http://www.cifor.cgiar.org 


\section{Table of Contents}

Table of Contents $\quad$ iii

Abstract iv

1. Introduction 1

2. Forest policy changes as they relate to Bulungan 3

3. The process of application for IPPK permits in Bulungan 4

4. Background on Bulungan and Sekatak 5

5. Earlier community experiences: HPH and the first wave of IPPK in Sekatak 7

6. Later community experiences: IPPK agreements and collective action 9

7. Discussion 14

8. Conclusions 17

Endnotes $\quad 18$

References $\quad 21$

Appendix 23 


\section{Abstract}

Since the reform of Indonesia's Forestry Law in 1999, newly empowered forest-dependent communities have been allowed to negotiate directly with logging companies for access to financial and social benefits. Fieldwork undertaken in May and June 2003 attempted to assess the impacts of this decentralization reform on communities in the subdistrict of Sekatak in Bulungan, East Kalimantan. Results suggest that the process of negotiations influenced the benefits that accrued to these communities. It seems that the most important factors were increased collective action and co-operation among the communities situated in and sharing forest areas, prior experience of dealing and conflicts with logging companies, plus strong and relatively transparent local leadership. Taken together these factors enabled communities to obtain benefits at the higher end of the scale for the area as a whole and provided a mechanism by which to deal with problems as they arose. These results suggest that in the absence of other means by which to protect the interests of local communities and to enforce the law, local capacities for collective action may be a potential and effective substitute for future development. 


\section{Introduction}

Since the fall of ex-President Suharto's centralized and autocratic government in 1997, the Republic of Indonesia has undergone rapid decentralization, which has resulted in changes to the institutions and processes governing the management of natural resources in the country (Barr and Resosudarmo 2002). Governance over forests has shifted in a haphazard manner, from a centralized system of logging concessions and protected areas to one now informally controlled by over 300 district-level governments. These changes have resulted in newly empowered forest-dependent communities exerting property rights over adat (customary) forest, leading in many cases to communities negotiating directly with logging companies 1 in exchange for access to financial and social benefits. Thus, for the first time ever, commercial timber harvesting operations have been paying fees and providing goods and services to communities in recognition of their presumed customary claims, although these are yet to be clearly defined in a formal legal sense (Wollenberg and Kartodihardjo 2002).

Previous empirical research in Kalimantan (see for example Barr et al. 2001; Anau et al. 2002) indicates a large variation in contractual outcomes and in actual benefits received by communities, i.e., financial payments and provision of consumer goods and public goods. The key observation from these studies is that compared to pre-decentralization, when the central government redistributed only a fraction of the timber rents from logging activities to the provinces, the decentralization reforms and direct negotiations have allowed local governments and forest-dependent communities to capture at least some rents. Despite the variation in these financial payoffs, their generally low level (see for example Palmer and Obidzinski 2002) and the lack of information regarding the ecological costs of logging ${ }^{2}$, it seems that relative to the situation prior to 1998 many communities have benefited financially from decentralization, at least in the short-term.
The purpose of this paper is to identify and analyse the conditions that may lead to this variation in contracted outcomes and benefits. Previous research suggests that variation among villages may result from the processes of negotiation (leading to agreements between communities and companies), the degree of contract compliance by the company and the degree of enforcement of the contract by the communities. Therefore, the impacts of decentralization on these communities and their subsequent empowerment may be better understood through an analysis of the processes underlying the formation of communitycompany agreements and their outcomes.

To explain the cited variation I asked whether there were any community attributes, such as ethnicity, size or level of dependence on the forest with respect to livelihoods, that appear to have significant impact on the processes that lead to outcomes. I analysed how negotiations were undertaken in communities, who negotiated with whom, the level of participation by community members and the types of agreements made. I also examined the company response to the agreements: do they keep the promises made to communities? If not, then what was the community response given that company contractual obligations are usually not formally enforced by the government (Richards et al. 2003)?

Community 'self-enforcement' and conflicts between communities and companies are recurring themes in Kalimantan, typically involving demonstrations and road blockades (see for example Obidzinski 2003). I was especially interested in the determinants of selfenforcement by communities given the weak capacity and interest of local government to this end. The literature suggests successful collection action by communities may result in more efficient management outcomes with respect to the use of natural resources (e.g. Ostrom 1990; see Baland and Platteau 1996 and Agrawal 2001 for reviews). What 
might affect community capacity for collective action in self-enforcement in logging agreements?

This case study focuses on how aspects of negotiation affected community access to logging benefits in the subdistrict of Sekatak in the district of Bulungan, East Kalimantan. I chose this subdistrict because of the effective nature of collective action among these particular communities and how this measure appeared to influence the processes and the outcomes of their logging agreements. Information for this study was obtained through interviews with key members of the 'village elite', subdistrict government officials and employees in the main village of Sekatak Buji, between May and June 2003. Also, interviews were conducted with local nongovernmental organisations and officials from the Bulungan forestry office in the district capital of Tanjung Selor and the town of Tarakan. This case study forms part of a larger, ongoing study on the processes of negotiation and the variation in benefits from agreements made between forestdependent communities and logging companies in East Kalimantan³.
First, I describe forest policy changes in Bulungan and their implementation on the ground. Next, I present background material on the villages and the study area followed by a description of pre-decentralisation community experiences with logging operations. These logging operations continued after decentralization reforms began and interacted with the newer operations that started after the first community-company negotiations in 1999. Here, I illustrate the early community experiences with negotiations and associated problems from 1999 until late 2000. By late 2000, however, the 'boom' in community-company agreements and associated problems in Sekatak led to a change in community negotiation strategy. This change seems to have involved more community-to-community collective action, which I describe along with the resultant contractual outcomes and the benefits that accrued to the communities in Sekatak. In the following section, I discuss these findings and the conditions that may have had a significant influence on processes and outcomes. The final section concludes. 


\section{Forest policy changes as they relate to Bulungan}

The reform of Indonesia's 1967 Basic Forestry Law in 1999, UU No. 41/1999, gave some provisions for the recognition of customary (adat) lands, while Government Regulation No. 6/1999 gave authority to district governments (Pemerintah Daerah or Pemda) to allocate Hak Pemungutan Hasil Hutan (HPHH, or Rights to the Harvesting of Forest Products) in areas classified as 'Permanent Forest Estate' (Kawasan Budidaya Kehutanan, or KBK). The implementation of regulations relating to $\mathrm{HPHH}$ was detailed in a series of decrees from the Ministry of Forestry and Estate Crops in May 1999 (Barr et al. 2001). Specifically, Ministerial Decision No. 310/1999 gave the head of a district (Bupati) the authority to distribute $\mathrm{HPHH}$ permits, which should be valid for no longer than one year and govern forest parcels no larger than 100 hectares. The beneficiaries of the permits were to be communities that lived in and utilized the forest in question and hence recognized many long-standing community land claims, typically for so-called adat forest (Suramenggala et al. 2001).

In 1999 and 2000, many districts in East Kalimantan took advantage of the new regulations to manage directly forests within their district boundaries by allocating large numbers of HPHHs (Barr et al 2001). Following this and in response to demands from communities for increased access to logging benefits, the district head of Bulungan with Decision No. 19/1999 provided for the issuance of small-scale forest conversion licenses known as Timber Extraction and Utilization Permits (Izin Pemungutan dan Pemanfaatan $K a y u$, or IPPK ${ }^{4}$ ). The ruling stipulated that IPPK permits could be allocated to allow timber harvesting associated with forest conversion in areas designated as 'Social Forest' (Hutan Rakyat) or 'Privately Owned Forest' (Hutan Milik), areas that are supposed to fall outside those classified as Permanent Forest Estate (Anau et al. 2001). In 1999 after logging companies began holding negotiations with villages in the district, 16 IPPK permits were issued for a total area of 3,740 hectares.
In 2000 the district head of Bulungan issued Decision No. 196 (2000) concerning the distribution of IPPK permits for the harvesting of forest wood products, forest ownership, forest people and adat forest in Bulungan. This ruling formally brought the IPPK system into line with the HPHH system in that each IPPK permit was supposed to be valid for one year only and for an area not to exceed 100 hectares $^{5}$. Moreover, this ruling stated that only regions of 'forest conversion' or 'production forest' which had already been 'converted', i.e. already selectively logged, could be allocated for IPPK concessions. These areas were generally located within the Permanent Forest Estate and hence gave the district government much more flexibility with respect to the geographic allocation of IPPK permits. In 2000, a total of 592 IPPK permits (comprising 59,200 hectares) were issued among 42 companies and approximately 30 villages in Bulungan 6 .

Decision No. 196 (2000) required that the following be made available to the Bupati's office before the district head may issue a permit.

- Written recommendations and signatures from the village head (kepala desa), the adat head and the subdistrict head (camat) along with a 'proposal', i.e. a written explanation of how activities in the proposed IPPK area would be conducted.

- The formation of a group of farming representatives (wakil kelompok tani) from the community, which is responsible for activities and forest management in the proposed IPPK area. Proof of compliance with this regulation is given in the form of a collection of signatures and copies of state identity cards of group members.

- Technical recommendations from the district forestry office and other departments (also including those from the provincial level), which would include appropriate forest maps etc. 


\section{The process of application for IPPK permits in Bulungan}

This process, as observed in many parts of East Kalimantan ${ }^{7}$, typically follows a number of steps with the involvement of a number of different actors ${ }^{8}$, perhaps most importantly the 'entrepreneur' or 'businessman' (pengusaha ${ }^{9}$ ).

1. An entrepreneur who, on behalf of a company (usually a $\mathrm{CV}^{10}$ ), approaches the district government and the community to propose an IPPK for the community's adat forest. This individual usually comes from the locality (sometimes even the same community) and would have some connections to the timber industry. His main role is to act as liaison among community representatives or village managers (usually the village head and adat head), the company and government officials.

2. If a community is interested in allowing a company access to the forest, then the entrepreneur, after having found an interested company, arrangea a meeting between company representative and subdistrict head, who will be asked for help in making a proposal on IPPK requirements and conditions.

3. Next, the entrepreneur asks for recommendations and signatures from the village head and adat head ${ }^{11}$, as well as for assistance with the formation of the 'farmers group' and the gathering of identity cards ${ }^{12}$. The recommendations are used to allow the transfer of adat forest from the community to the third party, i.e. the company, and usually, but not always, involve some meetings and discussions with other members of the community as well as the subdistrict head. Around this time, discussions invariably involve negotiations over benefits the community will derive from the transfer of forest, which is discussed in more detail for Sekatak later on.

4. These negotiations usually lead to an agreement or contract between the company and the community. The contract typically contains a list of proposed community benefits and company activities and is usually finalized and notarized in the town of Tarakan before being signed by representatives from both parties. This contract must be secured by the entrepreneur along with a map of the proposed logging area before an IPPK permit can be issued by the district government.

5. The entrepreneur facilitates co-operation among the private actors: the company (as the potential permit holder ${ }^{13}$ ), an investor (with the capital), the contractors (owning logging equipment, usually from Malaysia ${ }^{14}$ ) and the timber buyers (in the case of Bulungan, also from Malaysia). Sometimes, many or all of these functions are undertaken by the same individual.

6. Once co-operation and agreement have been secured from the private actors and the community, the entrepreneur facilitates cooperation among different offices and departments of the local government, mainly the district forestry office and the district head's office, to obtain the IPPK permit. 


\section{$4 \begin{aligned} & \text { Background on Bulungan and } \\ & \text { Sekatak }\end{aligned}$}

Before the political changes in 1998 and 1999, the old district of Bulungan consisted of three distinct areas that are now independent districts: Malinau, Nunukan and Bulungan. In 'new' Bulungan, there are five administrative subdistricts, or Kecematan: Tanjung Palas, Peso, Sesayap, Bunyu and Sekatak. Government data show that together the five areas consist of 85 villages and cover nearly 2 million hectares, with a total population of nearly 100,000 in 2000 (CDK $^{15}$ Bulungan Tengah 2000). The area that is the focus of this case study is the subdistrict of Sekatak.

Sekatak claims an area of approximately $8,800 \mathrm{~km}^{2}$, with territorial borders to Sesayap in the north, Tanjung Palas in the south, Malinau town to the west and Tarakan city and the sea to the east. Data from the district of Bulungan describe Sekatak as an area of $2,000 \mathrm{~km}^{2}$, composed mainly of forest and mountain ranges, with swamps where the territory borders the sea. Irrespective of which territorial size claim is the more accurate, Sekatak has 21 communities with a total population of approximately 7,000 divided among approximately 1,500 families (Kecematan Sekatak unpublished data). Three of these communities-Sekatak Bengara, Pungit and Pentian - are located near the swamp areas, where the Sekatak river opens out into the sea, while the remainder are to be found further inland.

The populations of 19 Sekatak communities are predominantly Dayak Berusu and Dayak Punan, while the villages of Sekatak Buji and Sekatak Bengara are mainly non-Dayak. Sekatak Buji is by far the largest community with 1,600 people spread among approximately 350 families. It is the only predominantly Muslim community in the area and has been in its current location inland from the opening of the Sekatak river for at least three generations since the 1800 s. The population is composed mainly of the Bulungan and Tidung indigenous groups, who claim to have descended from families in Tanjung Selor, a trading port and former base of a precolonial sultanate. Within this community, there are small minorities of Javanese and Timorese, in addition to even smaller numbers of people from Sulawesi, Madura and Toraja.

As a consequence of its ethnic composition, history, links, position (situated almost halfway between the towns of Tarakan and Tanjung Selor) and large size, Buji is unique when compared to most other communities in Sekatak. What distinguishes Buji is the fact that 17 (Dayak) communities have moved downstream within the last 40 years and have all relocated near Buji with the result that all these villages are within easy walking distance of one another (see Figure 1). The main reason for this relocation was to enable Dayak families to send their children to school in Buji, which now has at least three schools. However, as in other parts of East Kalimantan these types of movements have complicated land-use claims in Sekatak because of a lack of agreement about how to share local forest resources. Furthermore, subdistrict and other government administrative offices (e.g. police station) are all located in Buji, and economically Buji's experience as a trading post has been exploited by the local Dayak as well. In addition to forest products such as rattan and gaharu (used to make incense and perfume), Dayak antiques and baskets are exported via Buji to Indonesian tourist centres such as Bali and East Java.

However, livelihoods for most communities in Sekatak including Buji are still based on subsistence agriculture (padi, palajiwa, ladang) and fishing, as well as the trading of forest products, reflecting a general dependence on the forest and the river. A few people find employment as public employees of the subdistrict government, as teachers and with small companies (e.g. as mechanics). Infrastructure is poor. Former logging roads link some of the villages to Tanjung Selor and Malinau, but most people still travel 
by river. There has been electricity in all villages since 1995, when the government provided two large generators in Buji. Also, the road to the village was built in 1995 by a HPH (Hak Pengusahaan Hutan, or forest concession holder ${ }^{16}$ ) concessionaire. The only phone (satellite) in Sekatak is located in the house of Buji's village head and is used as the area's public phone.

Buji is apparently recognised by the other communities in the area as the 'strongest' community in Sekatak and the one that assumes leadership for all the others in the area. Hence, records kept by the village head in Buji usually include those for all villages in Sekatak and unsurprisingly there are strong links among the village head, the subdistrict head and officials from the local government office. The Buji village head is arguably the most powerful figure in Sekatak and is at least as influential as the subdistrict head. Up to 50 people a day from all villages in the area visit his house to pay their respects and to have their problems and disputes resolved. Furthermore, in the context of co-operation over land-use and IPPK negotiations, the village heads of all the other villages tend to defer first to the village head of Buji and not the local government officials.

Figure 1: Location of villages near Sekatak Buji plus Pangkalan logging (HPH) camp run by Intracawood and border of its logging concession area.

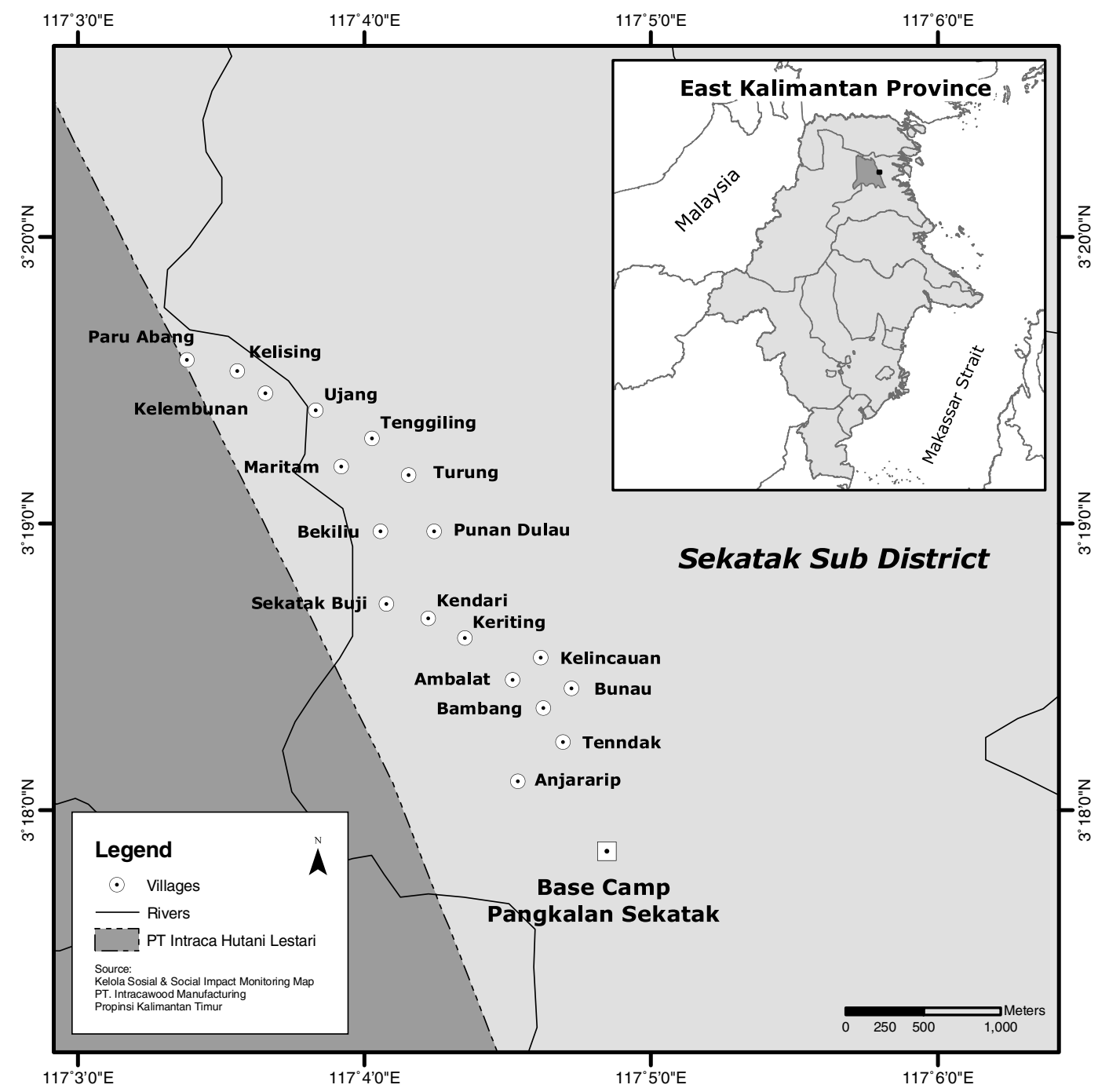




\section{Earlier community experiences: $\mathrm{HPH}$ and the first wave of IPPK in Sekatak}

\begin{abstract}
HPH in Sekatak
Buji claims a territory of approximately 100,000 hectares in Sekatak, half of which was logged by HPH and $\mathrm{IPK}^{17}$ concessionaires before 1999. PT Intracawood, operating on behalf of state-owned PT Inhutani I, has been the main $\mathrm{HPH}$ concession holder ${ }^{18}$ since 1976 with a concession of 250,000 hectares that covers forest in Sekatak and Bengalun (CDK Bulungan Tengah unpublished data). As of June 2003, it was the sole remaining HPH operator in Sekatak.
\end{abstract}

For all communities in Sekatak, previous experience with HPHs for the last 30 years have generally been quite bitter. Problems and conflict with $\mathrm{HPH}$ companies is a recurring theme in East Kalimantan both before and after the advent of IPPK (Yasmi 2003). For example, up until the road to Buji was completed in 1995, villagers were not informed and were apparently unaware of the HPH concession located so close to the village. In another case, the burial ground forest of a neighbouring Dayak community was logged by another HPH about 10 years ago. The HPH was forced to pay some compensation to the community after violent protests by community members. In 1993 the same company also built a mosque in Buji, although no financial compensation was provided until after the first IPPK entrepreneurs arrived in Sekatak in 1999 ( ).

Before 1999 the central government allocated HPH concessions in East Kalimantan and established them using spatial land planning set at the provincial level by the government of East Kalimantan. It used the classification of Permanent Forest Estate (KBK) and Non-Forest Estate (Kawasan Budidaya Non Kehutanan, or KBNK). However, these classifications have never really been completely accepted or recognized by communities in Bulungan (Suramenggala et al. 2001). Furthermore, so-called 'KBK regions' claimed by HPH companies also tended to be land considered as 'adat forest' by communities. Consequently when IPPK companies sought to negotiate for concession areas in
1999 and 2000, many were placed within KBK regions in HPH areas (see Appendix). This however, was not of any concern to the communities because in their minds their adat rights to this land were already 'stolen' by the HPH operations.

Soon after the first IPPK operations were established in 1999 in Sekatak (all in the Inhutani I/Intracawood concession area), conflicts arose between HPH and IPPK companies over the practice of IPPK companies to establish operations inside previously unlogged 'production forest' within KBK regions of the HPH concession area. Otherwise, the HPH operations appeared to tolerate the activities of IPPKs in 'converted production forest', land that had already been selectively logged by the HPH in the past or within KBNK regions. In Buji, where up to 50,000 hectares of relatively accessible HPH land (via old logging roads) has already been selectively logged, it was relatively easy for small-scale IPPK operations to enter this forest and extract the smaller trees ${ }^{19}$.

Consequently, the HPHs defended their concession areas, usually with 'hired members' of the security services such as the Indonesian Army. This was a situation that particularly angered the local communities as it implied 'business as usual' for the HPHs after the political changes of 1998-99. There is some evidence (see for example Suramenggala et al. 2001) that during HPH-IPPK conflicts, communities tended to side with the IPPK operations against the $\mathrm{HPH}$ operations, although it is unclear exactly how active the community role was during these disputes. For example in 2001, Buji 'confiscated' the roads and log pond previously established by Intracawood, because these were allegedly situated on its adat land. The village then used this seizure as leverage in extracting concessions from the HPH company such as ensuring that the IPPK company, CV Surya Ramadhan, had continued access to its roads and log pond. 
All these problems associated with adat forests located in HPH areas and conflicts between HPH and IPPK operators continued until May 2001, when the district head of Bulungan gathered together community owners of adat forest and managers of HPH and IPPK operations for the settlement of these land conflicts through discussion and cooperation (Suramenggala et al. 2001). Also, it is understood that the village head of Buji had a key role in facilitating discussions among the other village heads in the area during this time. Bulungan's district head moved all IPPK concessions allocated in $\mathrm{KBK}$ regions either to $\mathrm{KBNK}$ regions within the HPH area or outside the HPH areas altogether. Furthermore, in an attempt to prevent further HPH-IPPK conflicts in Sekatak, the district head has not issued any 'new' IPPK permits since the end of 2000 and has extended only some of those operating at that time (see below and Appendix). Most IPPK companies in Sekatak have continued to operate on land claimed by Inhutani I/Intracawood, some of which is still being logged by Intracawood. It seems that similar to the Inhutani II concession area in Malinau (Barr et al. 2001), many of the IPPKs had concluded some kind of deal with Inhutani I (or Intracawood) as a result of negotiations held in 2001. This deal would involve the use of old HPH logging roads as well as the infrastructure used to load logs onto log boats. Also, two HPHs operating in Sekatak closed shop in 2001, and many people who formerly worked for these have joined or 'merged' with the far cheaper and flexible IPPK operations ${ }^{20}$.

With communities proposing and preferring the new IPPK arrangements at this time, HPH operations were forced into negotiating similar agreements with communities. For example, Intracawood agreed to pay communities in Sekatak a fee of $\mathrm{Rp} 10,000 / \mathrm{m}^{3}$ of production. This indicates that there was some competition among logging companies, suggesting market power in favour of communities at this time.

\section{The first wave of IPPK negotiations and agreements: 1999 until late 2000}

In late 1999 the district head of Bulungan gave out four IPPK permits for a total area of around 2,000 hectares of forest in Sekatak. The villages involved in these deals, Sekatak Bengara, Buji, Pungit and Pentian (see Appendix) negotiated the agreements independently of one another. Following these initial deals, people from villages not participating started moving their families into villages, such as Buji, in order to share in the new benefits. This caused conflicts among villages that had already concluded logging deals and those not involved in the process, as well as between residents and newly arrived migrants within participating villages.

These problems continued into 2000, when Bulungan released further IPPK legislation, and were exacerbated when more villages opened negotiations with IPPK entrepreneurs for new concessions. In July 2000, Kelising made an agreement with CV Raya Bhakti and in August, Keriting and Anjar Arif made an agreement with CV Malindo Jaya Sekatak. At the end of August, the district government gave an extension to Sekatak Bengara and CV Mutiara Utama for another 500 hectares, which was soon followed by an extension given to Pungit and Pentian and CV Wana Prima Mandiri (see Appendix). The 'IPPK boom' in Sekatak had begun.

By this time all villages in Sekatak demanded their own agreements with IPPK companies and hence access to the benefits from these deals. However, while these villages justified their demands for independent deals with the problems created by people moving from village to village, problems related to contradictory forest land claims further intensified intervillage conflict. Communities in Sekatak already owned borders to local territories, shared some adat areas and tended to mutually respect borders among villages. But while communities could agree collectively on these areas, the more remote forest areas were disputed among villages. For example, Buji has a much larger and wider-ranging forest claim than all the other villages, although there are recognized overlaps with the claims made by the villages of Pungit and Pentian. Also, the situation vis-à-vis forest land claims was complicated by the past movements and habitations of the Punan and Berusu communities, who traditionally ranged across large areas. Thus, these communities sometimes laid claim to areas where they no longer lived or gathered forest products, similar to other areas in East Kalimantan such as Malinau (see Anau et al. 2001).

Until December 2000 there was, by comparison to events afterwards, relatively little co-ordination among villages and a number of problems eregarding adat and forest border claims. The situation was further complicated by conflicts taking place between $\mathrm{HPH}$ operations and IPPK operations situated inside their concession areas. Furthermore, there was some variation in benefits across villages that did participate in IPPK agreements. Buji for example claimed to have had better deals and received higher fees than all the neighbouring Dayak communities at that time. 


\section{Later community experiences: IPPK agreements and collective action}

\section{The second wave of IPPK agreements: Late $\mathbf{2 0 0 0}$ until June 2003}

In late 2000, intervillage conflict eased when Buji asserted its leadership over neighbouring villages to attempt to deal with contradictory adat forest claims and the problems associated with movements of people to claim logging benefits. Village heads met in Buji to discuss forest borders and allocate areas of adat forest. A system of identity cards was devised by the subdistrict government and Buji village elders to monitor the movements of people who relocated only to access the logging benefits negotiated by other villages. Furthermore, a system of checking on agreements was agreed upon to avoid future conflict (see next section). Thus, the problems and conflicts that arose in Sekatak in 1999-2000 led to some cooperation between all the villages making a claim to adat forest, with Buji as the 'leader' of all these discussions and negotiations. As a consequence, a greater number of villages in Sekatak started to make agreements with IPPK companies and obtain access to logging benefits (see Appendix). Of these, 178 permits were distributed in Sekatak for an area totalling 17,800 hectares among 20 (out of a possible 21) villages with a 'claim' for adat forest, according to the Forestry Office, Bulungan.

Apparently, however, at this time many land claims were discussed if not completely finalized. The fact that many Dayak were dependent on Buji for schools, electricity, trade and other links with the 'outside world' perhaps contributed to a mutual understanding of the situation, particularly as many Dayak settlements were relative newcomers to that part of the Sekatak river. Also, most of these communities had not been forced to move there by the government as part of a formal 'resettlement programme', as was the case in other areas of East Kalimantan, e.g. the village of Respen Sembuak ${ }^{21}$, located opposite Malinau town in the district of Malinau. Furthermore, many of the new IPPK concessionaires were allocated forest areas that overlapped Buji's land claim, a land claim that appeared to be stronger than that of the Punan and
Berusu communities-perhaps because of the long history of the Tidung Bulungan people in Buji, who have lived in a single location on the Sekatak river for many generations and claim much of the forest in the vicinity of the village. The Punan and Berusu communities on the other hand have historically never lived in the same location for more than a few years at a time.

\section{The process of community-company negotiations}

Evidence for the new spirit of co-operation among villages in Sekatak comes from negotiations that took place between the communities and IPPK companies towards the end of 2000. All the villages tended to be approached independently, but after these preliminary discussions, representatives from the Dayak community (usually the village head and the tokoh masyarakat, or prominent community members) and from the company ${ }^{22}$, along with the subdistrict head, all met, typically in the meeting room at the house of the village head of Buji, before any final agreement was made. Therefore, all the communities that had expressed an interest and had been approached by an 'entrepreneur' or company representative were first asked to gather together to verify the adat forest claims. Then, negotiations proceeded with all proposed agreements and areas to be logged overseen by the Buji village head and other prominent Buji community members.

Buji claimed that all the details of negotiations between Buji and IPPK companies were made public and that prior consultations were made with community members in a public forum. Hence, a broad consensus was reached in the community before the final decision by the village head, village elders and other prominent community members. They could not say, however, whether this process had occurred in other villages in Sekatak as well.

This process whereby representatives of all communities 
in Sekatak consulted with Buji community leaders during the process of negotiations contributed an element of security to these meetings in that there is no evidence of coercion or pressure from companies during these negotiations. Since Buji is at the centre of logging (HPH) infrastructure in the area, it used this as leverage in gaining cooperation from the rest of the villages. For example, the transportation of wood from Bekiliu relies on a road that goes through Buji and the use of a $\log$ pond that was claimed by Buji. Consequently, Bekiliu pays Buji a fee for the use of these facilities (Suramenggala et al. 2001).

The IPPK fees negotiated in Buji and other villages in Sekatak appear to have a 'fixed' limit of around $\mathrm{Rp} 50,000 / \mathrm{m}^{3}$, the observed maximum negotiated. One possible explanation for this ceiling is that even a fee of $\mathrm{Rp} 30,000 / \mathrm{m}^{3}$ is three times the amount being paid by the HPH to Buji. Another possible explanation is that the district head of Bulungan, along with the forestry office, receives a special 'tax' for every cubic metre of wood production ${ }^{23}$ in the district regardless of where it is produced, what species is logged, and whether the timber is exported or not. Consequently, according to an informant from the forestry office, the district head is obliged to provide a concession area within the boundaries of Bulungan. This suggests that the district head has the final say in whether or not logging takes place in the district. However in Sekatak, it seems that collective action by the communities could potentially stop logging in this area. If negotiations failed between the company and community (e.g. if the community asked for 'too much money' or if conflict between the community and the company became too difficult to manage), then the company would simply withdraw and be reallocated another concession area somewhere else in Bulungan. This appears to indicate market power in favour of companies in the district as a whole in contrast to the earlier indicators of communities having more market power in Sekatak alone $e^{24}$.

Some villages negotiated with the company mainly for the development of public systems and infrastructure in addition to some financial payments. These included education programmes, infrastructure, communal housing, and the provision of health services. Other villages, including Buji, preferred to negotiate fees for timber harvested, either because they already had the social infrastructure they needed or wanted at that time, or because they did not trust the IPPK companies to undertake such developments properly.

The community in Buji also indicated that acreages and approximate locations of forests proposed by
IPPK companies were decided in advance by the companies and non-negotiable. The proposed concession areas tended to be clustered in the same areas of Sekatak (see below). However, the actual borders of the proposed logging areas on the ground were negotiated and generally decided by the community, as would make sense given the poor quality of most government maps, particularly at the district level (Anau et al. 2001). Also, much of the spatial land planning undertaken in the past (usually by the provincial government) tended to be ignored both by the communities and by the district head. Thus, Buji negotiators insisted that IPPK companies situate their operations away from rivers in order to reduce the impact of soil run-off.

\section{Community-company logging agreements: negotiated outcomes}

In Buji, the village head and other prominent members arranged for an official agreement or contract to be drawn up for the transfer of adat forest to companies, which formalization was arranged and overseen usually by a lawyer from Tarakan ${ }^{25}$. Buji claimed that this arrangement allowed for more time for discussion and agreement with regards to formulating logging rules, such as concession borders and replanting.

As can be seen in the Appendix, up until 21 December 2000, the district head had issued permits on completely separate days for most villages involved in negotiations in Sekatak. On this date and afterwards groups of IPPK permits were issued at the same time. For example, on 21 December 2000, the villages of Bekiliu, Bunau Jalai, Kelincauan Kendari, Pentian, Pungit, and Terindak all received permits issued by the district head. All six villages had an agreement with a single company, CV Wana Prima Mandiri. Soon after, on 29 December, the villages of Bambang, Buji, Punan Dulau and Turung all had permits issued 2000. These villages had negotiated with four different companies, one of which was CV Wana Prima Mandiri again. This circumstance is significant because it suggests that there was an element of co-ordination among the villages and companies with respect to IPPK agreements.

From 2001 to 2003, six IPPK companies (see Appendix) have been operating continuously in Sekatak on behalf of a total of nine villages. The district government made the first extension (perpanjangan $I$ ) to their permits by the district government on 19 and 20 August 2002. The second extension (perpanjangan II) to all these permits was made on 24 February 2003, thus allowing the companies to operate in Sekatak for a third year. Again, these dates 
reveal an element of coordination among the participating villages and companies, particularly after the discussions in 2001 to resolve all outstanding HPH-IPPK disputes in Sekatak. Apparently the remaining villages in Sekatak either had their IPPKs moved by Bulungan's district head, perhaps to an area claimed by a different village, or had exhausted their land claim by the end of 2001 and hence had no more forest containing commercially valuable timber with which to negotiate with IPPK companies ${ }^{26}$.

Buji claimed that its agreement with the six companies was supposed to last a total of five years. Furthermore, the companies and all nine villages had sign up to the same contract ${ }^{27}$ with the following main points:

1. Length of logging operations

2. Quantity of wood to be extracted and area to be logged

3. Payment of fee to village head (advance payment and per cubic metre)

4. Logging rules

5. Replanting of logged areas

6. Social assistance

7. Boundaries of 'protection forest'

8. Wood for gardens and village buildings

9. Protection of burial grounds

Within the confines of this single contract there was flexibility in the provision of social facilities and financial payments, which appeared to be dependent on the needs and demands of each individual community and the size of the concession area. For example, Punan Dulau with a population of approximately 250 people negotiated a 1,500 hectares IPPK with PT Bhakti Bumi Perdana in which the company agreed build 29 houses, an adat meeting room and many other social facilities. The village of Turung on the other hand, with a population of less than 100 people, negotiated a 600 hectares IPPK with CV Gunung Lestari in which the company promised to provide a new roof for the adat meeting room and wood for other village buildings (Suramenggala et al. 2001). The sum total of these 'social benefits' in Turung was a lot less than in the larger village of Punan Dulau. Hence, it seems that the overall sum of social benefits rose in proportion to the approximate size of the community.

While the provisions for noncash benefits varied, cash benefits for the villages and logging rules for the IPPK companies were the same. The advance payment agreed upon was Rp250 million per village, to be paid in three instalments plus a fixed fee of Rp30,000 to Rp50,000 per cubic metre depending on the wood species harvested. The higher amount tended to be paid for meranti. None of the villagers were offered jobs with the companies, apparently because villagers had no previous experience working in logging operations. Instead, all the IPPK workers were contracted from outside the area, from both Tarakan and other places further away.

Villagers in Buji say that the negotiation of 'adat borders' has allowed them to divide up the concessions into different 'blocks', so that when one area has been logged the company must replant before moving on to the next 'block'. This arrangement also may have helped simplify the monitoring process that was established by the communities (see below). IPPK regulations also insist on replanting, although precise details may be negotiated between communities and companies $^{28}$.

For the six IPPK extensions issued in 2003, Buji claimed that an area of 1,500 hectares was agreed upon in two separate locations of Sekatak, although the permits listed in the Appendix suggest an area of over 4,000 hectares (and probably more due to underreporting by the companies). In this discussion Buji did not 'count' the area that had already been allocated to an HPH (whether operational or not), only the land that was newly allocated by the village itself for logging activities. This suggests that Buji was discriminating between the areas of its land claim that lay inside and outside the HPH concession areas. The discrimination in forest areas may be an indication of the relative strengths of forest claim as perceived by the village. A long history of HPH activity in Sekatak may have resulted in Buji perceiving a stronger claim on forest outside the borders of the HPH concession areas. Thus, IPPK activities situated within HPH areas may not be as carefully regarded as those outside, particularly since a majority of Buji's land claim has already been logged at least once by concessionaires.

The size of forest areas proposed and agreed upon for IPPK concessions in many of these cases does not seem to match the areas that appear on the IPPK permit and hence the records of the local forestry office. For example, an agreement between CV Malindo Jaya Sekatak and the villages of Keriting and Anjar Arif described an area of 2,100 hectares in the vicinity of the two villages and on the site of land claimed by Inhutani I/Intracawood. Records held by the Bulungan Forestry Office stated that Malindo Jaya Sekatak was issued an IPPK permit on 16 August 2000 for an area of 500 hectares, less than a quarter of what was actually agreed upon (see Appendix). Even if one were to assume that the agreement between IPPK company and village also incorporated the areas on both subsequent IPPK permit extensions, i.e. 500 plus 
200 plus 200 hectares, then this total area, i.e. 900 hectares, would still be much smaller than the area agreed upon by the communities and company in 2000. IPPK companies in East Kalimantan typically underreport proposed concession areas in order to get away with underreporting their wood production figure ${ }^{29}$ to government offices and hence pay less $\operatorname{tax}^{30}$ to the district government (see Palmer and Obidzinski 2002). Alternatively, similar to Buji, it is possible that many of the villages in Sekatak have five-year agreements with the companies, which would then only require a constant stream of IPPK permit extensions. Therefore, the agreed upon logging area would almost certainly exceed the area of the permit for any given year, although in Keriting and Anjar Arif's agreement there is no contractual time frame. This agreement is effectively open, meaning that the company can log until it reaches 2,100 hectares irrespective of how long this takes.

\section{The distribution of benefits within villages}

Along with problems associated with land and property rights claims in many parts of East Kalimantan such as Malinau and Bulungan, another major issue is the lack of transparency in the distribution of IPPK benefits within villages (Limberg 2003). Suramenggala et al. (2001) report that in Bulungan there were many village and adat heads who displayed a lack of transparency during negotiations and in receiving money from companies. Their study also recorded that community members perceived IPPK fee payments as either not being 'fairly distributed' or not received at all.

In Buji, records exist of lists of households in the village that had been allocated equal shares of payments the company made to the village head ${ }^{31}$. The head of household had to sign off on the receipt of money from the village head. There were also records of money set aside for scholarships for students to study outside the village and funds established for future village developments ${ }^{32}$. One problem was that even after receiving a share of benefits, some villagers ask the company for more money once the contract has been concluded, a situation that occurs in other villages in Sekatak as well. Perhaps people did not receive their full entitlement from their respective village heads or village elites, or perhaps they did not feel justly compensated in the first place. The former is more likely to occur if a village head has chosen to keep more of the financial benefits intended for the whole community. In the case of Buji, however, records held by the village head showed that he negotiated for, and received separate fees as well as having received and distributed fees for the rest of the community. These separate fees were counted as administrative costs by Buji village head staff for conducting negotiations on behalf of the whole village.

\section{Contract non-compliance and self-enforcement}

Conflicts between villages and companies usually began when a company, even after having already started production, failed to keep promises made to a community in the agreement. This failure on part of the companies to live up to the agreement is a common situation throughout East Kalimantan (e.g. see Anau et al. 2001; Barr et al. 2001; Limberg 2003) and one encouraged by a complete lack of law enforcement by local governments (Richards et al. 2003). From 1999 up to the present, problems continued with both HPH and IPPK operations failing to comply with agreements they had entered into with communities in Sekatak ${ }^{33}$. Examples of noncompliance included incursions in protection forest, nonpayment of fees and failure to replant logged areas. In other cases, village building was not performed as a result of it being calculated within the fee, although villagers claimed that they were not informed of this provision when the agreement was being negotiated.

Consequently, communities in Sekatak resorted to enforcing the agreements themselves, collectively, with periodic checks to ensure that companies were complying with the terms of the contract. First, community members checked that the IPPKs were not operating outside the boundaries of the concession area (e.g. in protection forest). Second, community members checked the volume of wood being produced because underreporting by IPPK companies had long been suspected. Checks were usually undertaken by counting the freshly cut timber stored in the log pond before transportation downriver, the only method of timber transportation in Sekatak. Third, people checked that companies were replanting the areas, or 'blocks', that had just been logged. People in Sekatak were assigned to check on the companies' activities every two weeks and report back transgressions to the village head, usually the one in Buji.

When a company logged outside the concession area, the village head in Buji would first call the company and the local government to try to resolve the situation. The police would also be informed, although villagers knew from previous experience that the police would always be paid off by the company when problems arose. Then the company would be given a few days to pay compensation of Rp5,000 per cubic meter in addition to the normal fee for all wood taken from forest logged outside the agreed zone. If the penalty was not paid, community members would 
confiscate logging equipment, perhaps the machines used to load logs onto the boats. This action had the effect of completely shutting down company operations since there were no alternative means of transporting timber out of Sekatak. Records held by the village head in Buji included letters from companies asking for the return of their equipment. Further noncompliance by the company usually resulted in it being asked to leave the area altogether.

\section{Mediation and the role of local government}

Before situations reached this stage, there were typically periods of mediation and meetings to try to resolve these disputes. The subdistrict head would attempt to facilitate dialogue between the community and company, along with government officials in Tanjung Selor. But when these people were seen as speaking on behalf of the company, the 'facilitation' reportedly only made the situation worse (Suramenggala et al. 2001). Many of the officials in these institutions had an intense (complicit) involvement in the chain of IPPK implementation, right up to the district head level. These networks of overlapping interests, from the Malaysian timber buyers all the way to the bureaucrats in forestry offices, are prevalent in many forest areas in Indonesia including East Kalimantan (Palmer and Obidzinski 2002). There tended to be little involvement of government authorities at the provincial level. The district head had ultimate authority, although the community perceived the head's actions relating to the settlement of conflicts to be 'biased' and suspected that the head may have been taking 'special fees' from IPPK companies.

If discussions on the resolution of a conflict between a company and a community reached deadlock, the company usually proposed a meeting with prominent community members in Tarakan or Tanjung Selor to renegotiate the agreement and perhaps make a new one. This is a common approach which has also been observed in Berau (Obidzinski 2003) and in Malinau (Limberg 2003) and in which accommodation is provided, sometimes along with the provision of cash, alcohol and prostitutes. If a compromise was not reached and a 'new agreement' not made then the district government would try to determine and resolve the problems between the two sides. In extreme cases, the district head in Bulungan simply moved the IPPK company's concession area elsewhere.

In Sekatak, where all the companies entered into the same contract terms and hence had to comply with the same rules and pay the same fees since 2001, there appeared to be some kind of mechanism for when a company leaves (because of either being shut down by the communities or being relocated by the district head of Bulungan). Buji treated all the IPPK permits as a 'single concession area' meaning that when one of these companies left, the others on the contract were then allowed to take over forest previously allocated to the one that had just left. This possibly induced competition for 'good behaviour' among the remaining companies on the contract ${ }^{34}$.

Since 2000, this 'single area' has been divided into two areas with two companies operating in one area and four in the other. Both of these areas were situated downstream of villages, one to the northeast of Buji with a logging camp on the north side of the Sekatak river, the other to the southeast of Buji. This area also included the log pond with Intracawood on the south side of the river. While both of these areas were still operational as of June 2003, it seems that in spite of IPPK permit extensions being granted to all six companies in February 2003, four of the companies had already left either because of having completed operations in the existing concession areas ${ }^{35}$ or because of being 'closed down' by the communities. As of June 2003, there were only two IPPK companies still in operation, one in each area, in addition to the $\mathrm{HPH}$ company, Intracawood. 


\section{Discussion}

Decentralisation appears to have inadvertently given a large element of control and autonomy over forests to local governments with resulting benefits to communities in Sekatak. However, from the start of company-community negotiations in 1999 until the 'IPPK boom' in late 2000 and the resolution of IPPKHPH conflicts in 2001, there were many problems with forest land claims and participation in logging deals among villages. There was a high level of tension among communities in Sekatak resulting from villageto-village conflicts arising from overlapping land claims, as well as tensions within villages stemming from movements of people from village to village. All this discord was the consequence of independently negotiated agreements and the relatively uncoordinated process of negotiations in Sekatak at the time. Company noncompliance occurred in some cases and led to variation in community responses, which may have been partially dependent on whether or not communities 'sided' with the IPPK against the $\mathrm{HPH}$ operations.

Since late 2000, increased cooperation among villages seems to have allowed for resolution of some problems related to land-use claims and competition over forest areas, although community property rights remained weak. Also, since 2000 nearly all villages in Sekatak participated in negotiations for access to logging benefits. Hence, after 2000, increased participation and co-operation among villages almost certainly changed the negotiation process relative to the earlier situation. Whereas before all participating communities negotiated independently, the process changed to one where representatives of other communities gathered together in Buji to discuss proposed IPPK deals.

This change in the negotiation process brought about by collective action may have also resulted in increased community control over the location of IPPK concession borders and the terms of logging such as replanting requirements. Relative to many other cases already recorded in East Kalimantan, and particularly in Bulungan, the contracted outcomes negotiated in Sekatak contained more terms and rules for the companies and promised fees were situated at the higher end of the scale. The linking together of all individual IPPK contracts into a single framework contract between the communities and companies seemed to lead to less variation in promised benefits among communities. However, many of the contracted outcomes (whether in terms of money paid, concession borders or other delimiters) may not have been realised without the establishment of a system of collective monitoring and contract enforcement.

In Indonesia as a whole, the absence of effective stateled enforcement with respect to forest governance (for example, see Richards et al. 2003) has meant more emphasis on the establishment of local systems of enforcement such as the one in Sekatak. The system was simple, had a clear chain of reporting and consequently appears to have been relatively successful in keeping company transgressions, including the $\mathrm{HPH}$, in check. However, as in many parts of East Kalimantan, the IPPK record of contractual compliance in Sekatak is remarkably poor. The reasons why IPPK operators have consistently failed to respect their side of the contract probably are the desire to maximise profits or some combination of incompetence and negligence. The fact that company compliance does not seem to have improved over time may indicate a profit-maximizing strategy, although the shutting down of numerous IPPKs in Sekatak makes this point difficult to observe properly. It should also be noted that while the IPPK companies have different owners, the nature of business networks in East Kalimantan ${ }^{36}$ might lead to them behaving more like a cartel rather than competing firms. However, while there appeared to be little change in the incidence of company noncompliance over time, there has been increased coordination among communities 
to deal with the it. Buji claimed that in general it refused to be drawn into compromising over contractual obligations when community-company conflicts arose and instead simply issued ultimatums for compensation before threatening to shut down operations.

The village of Buji facilitated increased communityto-community cooperation. Buji is relatively large and well-established, with a longstanding, large forest land claim. It is also unique in that it is an influential community with dominance over all other communities in Sekatak. This dominance is due to trade links, location (near other villages and $\mathrm{HPH}$ infrastructure) and influence with the subdistrict government, amongst other things. It may also be significant in attempting to explain collective action in Sekatak that Buji is non-Dayak. Maybe Buji is respected by the other villages in the area simply because it is ethnically unlike them. However, Buji is still a community that has had similar negative experiences with HPH concessionaires both pre- and post-1998. This experience may have helped the village in learning how to deal with IPPK operators, particularly with respect to contractual noncompliance. Buji also has a strong leader, who is the main point of reference not only for his own village, but for all the villages in the area. In addition, he has had experience in dealing with situations of conflict and seems to have had the competence and ability to prevent conflicts about land-use claims from deteriorating further in 2000 and 2001. From that time onwards, he was well placed to push for collective action by all villages in the area, leading to increased co-operation with respect to IPPK negotiations and contract enforcement. Since late 2000, there has reportedly been a sharp dissipation of intercommunity tension in Sekatak.

Some aspects of negotiations observed in Sekatak have also been observed elsewhere in East Kalimantan, where problems of overlapping and contradictory forest land claims are common. Hence, where villages are clustered relatively close together, share forest areas and may even have a history of co-operation, there are cases of co-operative agreements and the sharing of logging benefits among communities. However, it seems that strong and relatively transparent local leadership is necessary to enable collective action to work properly. An example in the district of Berau shows how collective action among villages in a single watershed with strong local leadership set the agenda and led to a single agreement. They even opposed logging, at least for a short period of time (Obidzinski personal communication; Palmer and Obidzinski 2002), although this stance eventually broke down following the acceptance by the leadership of a large fee from a coalition of the logging companies in the area. Thus it seems that in many relatively poor villages in East Kalimantan the sudden appearance in the local economy of large amounts of cash from IPPK deals and rent-seeking by well-placed 'village elites' may help explain the success of collective action by communities.

Rent-seeking can adversely affect the processes of negotiations, company compliance and selfenforcement. Anecdotal evidence (e.g. Anau et al. 2001) suggests that intracommunity problems are endemic in the entire province and that rent-seeking by 'village elites' is one of the main causes. Hence, while it cannot be directly observed, rent-seeking can be described as an 'unproductive activity' (e.g. Pearce in press) in that it imposes costs that may well outweigh the financial gains. Conflicts within communities may occur not just because of the in-migration effects of IPPK agreements. A general unhappiness amongst some village groups over the process of negotiations (e.g. lack of participation), the terms of logging agreements with companies and the distribution of benefits within villages can all lead to intracommunal tensions. All these problems can be caused or exacerbated by rent-seeking in the community, and potentially undermine the effectiveness of collective action taken by communities, whether taken by communities alone or by groups of communities as in the case of Berau. Collective action can be affected for example in terms of a breakdown in trust among different village groups and a breakdown in village decision-making. Therefore, where rent-seeking appears to be a serious problem, it would be important to consider its impacts and costs when calculating the overall benefits from postdecentralization logging agreements.

In spite of the empowerment and autonomy evident in Sekatak it was clear that villagers still did not feel they had a lot of choice in deciding whether to accept new logging deals or not. Current political uncertainties in the country, the haphazard nature of the recent political changes and weak property rights appear to affect people's perceptions of independence and autonomy. The fact that large areas of forest in Sekatak are still designated HPH areas may act as an incentive for these communities to continue to negotiate logging deals on their own terms for as long as possible. Furthermore, economic uncertainties and increasing cash demand in Sekatak do seem to affect decision making with regard to logging deals. Also, while there seems to have been some provision for reducing local damage through negotiation, e.g. with the establishment of logging borders and replanting 
requirements, it is highly unlikely that all ecological costs have been sufficiently internalized through these deals ${ }^{37}$. However, the lack of similarly high cashearning alternatives to logging is likely to result in more forests being negotiated over and transferred to logging operators in the near future. Since 1999, 10,000 to 20,000 hectares in total have been logged by both HPH and IPPK concessionaires in the 100,000 hectares claimed by Buji. The remaining 30,000 to 40,000 hectares is spread among six different areas of forest in Sekatak. 


\section{Conclusions}

At this point in time, decentralization changes have undoubtedly led to a higher capture of logging rents by communities in Sekatak and hence significantly altered the distribution of financial benefits from logging since 1998. These changes have resulted in variation among villages of benefits from logging agreements made with companies. This variation seems to be dependent on the processes of negotiation, company contract compliance and community enforcement. In Sekatak from 1999 until 2000, a number of communities were negotiating with companies independently with varying contractual and actual outcomes. Overall, these negotiations led to variations in social benefits and fees, as well as intercommunity and intracommunity conflicts arising from forest land claims and the movements of people to secure logging benefits in other villages. The situation of IPPKs in HPH areas led to further conflict that confused the forest land claim issue even more. Given all these problems, it seems that some communities benefited from these logging deals at least financially and in spite of widespread company noncompliance.

Conflicts over forest borders and benefit sharing among villages led to the assertion of leadership by Buji over the other communities in Sekatak. This leadership and the increased cooperation among communities resulted in the formation of a single contract that linked together several IPPKs and communities. Nearly all communities in Sekatak were included in this contract, which ensured a more equitable outcome for communities. Furthermore, a simple system of monitoring and contract enforcement by all communities participating in the agreement was established to deal with incidents of company noncompliance. These events were influenced by experiences during the first wave of IPK negotiations in 1999 as well as experiences with the HPH companies in Sekatak, both before and after decentralization. The relatively transparent leadership and influence of Buji was significant in enabling this process of cooperation among villages and sustaining it over time. Overall, the experience of Sekatak seems to imply that local collective action has improved local benefits from decentralization. A more transparent and coordinated process of negotiations was implemented for all participating communities and there has been a lower incidence of community-tocommunity conflict since late 2000 . While company noncompliance was still widespread as of June 2003, the coordinated system of monitoring and enforcement ensured that something was always done about it.

The case of Buji suggests that prior experience with conflict, strong leadership and coordinated action can lead to better benefits for communities. It also suggests that strategic points of leverage for communities exist when they can establish systems to monitor company activities in logging areas, log production and the rehabilitation of logged areas. In the absence of other means to protect the interests of local communities and to enforce the law, the development of capacities for such collective action and self-enforcement seem to be promising areas of further work. 


\section{Endnotes}

1 Engel et al. (2003) demonstrate how bargaining between community and company would be the outcome if the community were able to exert property rights over the forest, however vaguely defined or uncertain these rights might be by law.

2 Prior benefits associated with use of the forest, e.g., the gathering of forest products such as rattan or rubber, may also be lost as a consequence of logging activities. However, the larger the value of the standing forest as perceived by the community, the more likely the community will opt to prevent any form of logging, as has been observed in at least one area of East Kalimantan (Engel et al. 2003).

This larger body of research is being undertaken by Determinants and Effects of Alternative Institutions for Natural Resource Management in Developing Countries, a research group based at the Center of Development Research, University of Bonn and in collaboration with the Center for International Forestry Research, Bogor, Indonesia. All research is funded by the Robert-Bosch Foundation.

4 The reasons why Bulungan passed legislation relating to IPPK and not HPHH permits are not completely understood. One may be that the provincial government has to sign off on $\mathrm{HPHH}$ permits whereas IPPK rules only require that the negotiating parties make direct arrangements with the district head. Hence, the issuance of IPPKs may have required less bureaucracy, time and dealings with the provincial government of East Kalimantan. Also, IPPK regulations in Bulungan clearly state that forest clearance should be followed by plantation development or agricultural activities by the permit owner, in lieu of any formal reforestation tax to the government. Thus, it is possible that the district government of Bulungan adopted IPPK legislation in order to encourage plantation development once the forests were cleared of commercially valuable timber. On the ground and in practice, however, there has been very little to differentiate between HPHH and IPPK activities, and the terms HPHH and IPPK are used interchangeably in many areas of East Kalimantan.

5 But as is the case in many other districts, almost all companies obtain 'an IPPK' for an area far larger than 100 hectares, e.g. for 1,000 hectares, the company would receive 10 permits. Also, permit 'extensions' (perpanjangan) were typical and hence most IPPK permits would be valid for a period of at least two years instead of just one.

6 Since 1999, thousands of IPPK permits have been issued in East Kalimantan, with concessions cumulatively covering hundreds of thousands of hectares of forest land (Barr et al. 2001; Palmer and Obidzinski 2002; Obidzinski 2003).

7 For example see Obidzinski (2003) for Berau, Suramenggala et al. (2001) for Bulungan and Limberg (2003) for Malinau.

8 Many of these actors, particularly the government officials, charge special 'administrative fees' for their 'services'. These fees are known locally as 'pungutan liar' or 'wild tax (levy)'. See Suramenggala et al. (2001) for more.

9 The less formal Indonesian word for this individual is calo, which carries derogatory overtones. He is perceived mainly as an opportunist.

10 From the Dutch Commanitaire Vennootschap, meaning a limited partnership, among investors, brokers/dealers and various contractors.

11 According to Suramenggala et al. (2001), the village head and the adat head usually negotiated separate 'royalty payments' from the company, which in 
Bulungan was reported to be in the region of $\mathrm{Rp} 6,000$ to $12,000 / \mathrm{m}^{3}$ of wood production. In some cases this payment is perceived as another 'administrative fee' by village head and adat head for conducting the logging deal on behalf of the rest of the village.

12 But this group only becomes a legitimate tool in order to obtain the permit and start up operations. Suramenggala et al. (2001) note that there is no evidence that these groups have actually undertaken any kind of activities. The report further notes that group members were typically unaware that their signatures were in fact necessary for becoming permit owners and instead were being used to allow people from outside the community to become owners of the IPPK permit.

13 According to the Bulungan IPPK regulations, the permit owner is supposed to be a village cooperative, but instead is usually someone local who will represent the interests of the company and the village elite at the same time. Thus, within this framework the permit owner would technically be an 'employee' of the company. This is why signatures and identities of the village head, other important village representatives and the 'representative farming group' are so important in allowing companies access to community forests, because then the 'permit holder' does not legally have to be someone from the village.

14 Proof of this claim comes in the form of lists of logging equipment sent by the companies to the village of Sekatak Buji.

15 Cabang Dinas Kehutanan or the Provincial Forestry Service.

16 Typically large concessions, the permits for which are still allocated and controlled by the central government in Jakarta.

17 Izin Pemanfaatan Kayu, or Wood Utilization Permit, typically for forest clearance and plantation development.

18 The others are PT Bina Lestari (47,000 ha, also covering forest in Sesayap) and PT Karyasa Kencana $(13,525$ ha in Sekatak). Both were operational in 2001 but had ceased by June 2003 .

19 Typically, HPH operations would remove only trees of diameter $50 \mathrm{~cm}$ or greater. An agreement between CV Malindo Jaya Sekatak and the villages of Keriting and Anjar Arif stipulated that the company pay a fee of Rp200,000 per cubic metre for all logs of size greater than $50 \mathrm{~cm}$. Discussions revealed that the villages never received that sum because there were no logs of that size left in the IPPK concession area after the past logging there by a HPH company. This suggests that before decentralization less logging of smaller trees occurred. The logging of smaller trees by IPPKs may cause even greater damage to the forest as more tree cover is removed, which could imply an environmental cost associated with decentralization. Villagers claim that forest damage has become worse since the onset of IPPK in 1999. The biggest complaint was related to river levels (increased flooding in the wet season and too low in the dry season) and the poorer quality of river water (from increased soil run-off). Thus, there was some awareness of the local impacts of logging, which has been reinforced by experiences that some members have had outside the area, e.g. when people fly over logged-out areas of East Kalimantan.

20 IPPK operations tend to be far cheaper to operate, require a lower payment of formal taxes and entail less bureaucracy (see for example Obidzinski and Suramenggala 2000).

21 'Respen' means Resettlement penduduk or population.

22 Buji claimed not to deal with 'entrepreneurs', only the head of the IPPK company, e.g. the person who negotiated on behalf of CV Malindo Jaya Sekatak for an agreement with the villages of Keriting and Anjar Arif was a Peter Lukito, a 'Director' of the company. This person was also the IPPK permit holder. It should be noted however, that many of these 'CV' were in fact composed of no more than a few people.

23 According to the informant, every company pays fees of Rp5,000 to the district head and of Rp3,000 to the district local government for every cubic metre of production.

24 In theory, if all communities in Bulungan were able to act collectively, this could give market power to communities in the whole district. The district head would then find it very difficult to find a new concession area for the company. In practice, the size of Bulungan and the remoteness of many of the communities would probably make collective action on this scale rather difficult.

25 Some villages arranged for the transfer of their adat forest using only an oral agreement with few formal rules, as occurred in Berau (Palmer and 
Obidzinski 2002), Bulungan (Suramenggala et al. 2001) and Malinau (Anau et al. 2001). Many of these villages received only the advance payment (uang panjarfee), which could be demanded before operations commenced. The remainder of company promises typically went unfulfilled.

26 According to a forestry office informant, at least one village in Sekatak that had already negotiated away its land claim in 2000 has tried to 'tax' the log boats when they passed this village on their way downstream. It is unclear whether this action was taken in order to compensate the village for logging impacts that occurred upstream.

27 Note that there are separate agreements, although they tend to be drawn up in order to assist the company in obtaining the IPPK permit from the district government. All these separate agreements were collectively part of a single framework controlled by Buji. In discussions, Bulungan forestry officials said that they were completely unaware that all the IPPK permits issued for Sekatak were in fact linked together in a single agreement.

28 In Sekatak, the establishment of fruit gardens and jati or teak plantations was negotiated into the IPPK contracts.

29 The practice of underreporting is well-established. Discussions with a forestry office informant revealed that regular checks of the log pond in Sekatak showed that IPPK companies underreported log production to the local forestry office y by a factor of between 2 and 3. It seems that while these companies could deceive government officials, they may have been more 'truthful' with communities with respect to the size of proposed concession areas. Communities in Sekatak may be better placed to tell the difference between 500 and 2,100 hectares. The forestry office informant also added that when forestry officials complain of company underreporting, they were usually overridden by orders from the office of the district head.

30 If timber is to be exported from Bulungan, IPPK companies are supposed to pay Rp165,000 per cubic metre for meranti and Rp100,000 per cubic metre for other species to the local government. If timber is not to be exported, then the companies are supposed to pay the 'IPPK tax' of Rp65,000 per cubic metre for meranti and Rp50,000 per cubic metre for other species.
31 Remittances were paid into the village head's bank account in Tanjung Selor before being distributed among community members. Apparently at least one in five households in Buji had a bank account.

32 In Buji up to Rp25,000 per cubic metre was set aside for village developments such as improvements to village administration (e.g. purchase of computers) and the village schools. In 2003, Bulungan's district government ranked Buji second in the district for 'best use of IPPK money and village development'. This ranking was based on business activities, quality of administration, village activities, leadership etc.

33 The general impression is that for many people in Sekatak it is difficult to infer which experience was 'worse'-HPH or IPPK.

34 The firms on this particular contract have different owners. However, a relatively small number of individuals own many IPPK companies, e.g. CV Prima Wana Mandiri and CV Prima Wana Bakti, which although being the 'same company' operate in different subdistricts, Sekatak and Sesayap, respectively. If all the companies were owned by the same person, noncompliance could be viewed as a profit-making strategy. Some firms would benefit from noncompliance and there would be no real loss if another firm belonging to the same owner took over the concession area.

35 While the IPPK permit extensions were granted in February 2003 in theory to allow for another year of operations, some of the companies possibly only needed a few more months in order to finish existing concession areas. These permits were not issued in order to establish new concessions.

36 See McCarthy (2000) and Obidzinski (2003) for examples in Aceh.

37 For example, where there has been extensive logging in old, previously logged HPH areas, IPPK logging may have disturbed the process of forest regeneration and caused greater environmental damage leading to impacts on the gathering of other forest products such as rattan. In addition to these local externalities, there are also national and global externalities, since individuals outside the immediate locality may also suffer the consequences of forest conversion, e.g. the loss of existence or passive-use values (Krutilla 1967) and values relating to climate change (see for example Ramirez 2000). 


\section{References}

Agrawal, A. 2001 Common property institutions and sustainable governance of resources. World Development 29(10): 1649-1672.

Anau, N., Iwan, R., van Heist, M., Limberg, G., Sudana, M. and Wollenberg, E. (2001), Negotiating more than boundaries: conflict, power and agreement building in the demarcation of village borders in Malinau. Center for International Forestry Research, Bogor, Indonesia.

Baland, J.M., and Platteau, J.P. 1996 Halting degradation of natural resources: is there a role for rural communities? Food and Agriculture Organization of the United Nations (FAO) and Clarendon Press, Oxford.

Barr, C. and Resosudarmo, I.A.P. 2002 Decentralisation of forest administration in Indonesia: community livelihoods and economic development. Center for International Forestry Research, Bogor, Indonesia.

Barr, C., Wollenberg, E., Limberg, G., Anau, N., Iwan, R., Sudana, M., Moeliono, M. and Djogo, T. 2001 The impacts of decentralisation on forests and forest-dependent communities in Malinau District, East Kalimantan. Decentralisation and Forests in Indonesia Series: Case Study 3. Center for International Forestry Research, Bogor, Indonesia.

Engel, S., López, R. and Palmer, C. 2003 Communityindustry contracting over natural resource use in a context of weak property rights: the case of Indonesia. Keynote presentation to EAAE Workshop on Contracts in Agriculture, Copenhagen, June 19-21, 2003. Paper to the Annual Conference of the International Society of New Institutional Economics in Budapest, Hungary, September 2003. Submitted to Environmental and Resource Economics.

Krutilla, J. 1967 Conservation reconsidered. American Economic Review 57: 777-786.

Limberg, G. 2003 Hutan, desentralisasi dan suku. CIFOR Report. Center for International Forestry Research, Bogor, Indonesia.
McCarthy, J.F. 2000 Wild logging: state agency, district networks of power and interest, and biodiversity conservation in south Aceh, Sumatra. Asia Research Centre, Murdoch University, Australia.

Obidzinski, K. 2003 Logging in East Kalimantan, Indonesia: the historical expedience of illegality. Ph.D. Thesis, University of Amsterdam.

Obidzinski, K. and Suramenggala, I. 2000. A comparison of costs and expenses for HPH, IPPK and illegal logging. Mimeo, Yayasan Pionir Bulungan, East Kalimantan, Indonesia.

Ostrom, E. 1990 Governing the commons: the evolution of institutions for collective action. Cambridge University Press, Cambridge.

Palmer, C. and Obidzinski, K. 2002 Case study prepared for the report: 'Higher international standards or rent-seeking race to the bottom? The impacts of forest trade liberalisation of forest goverance.' Food and Agriculture Organisation (FAO) and the International Institute for Environment and Development (IIED). Project GCP/INT/775/JPN. Mimeo, Center for Development Research, Bonn, Germany.

Pearce, D.W. In press. Environment and economic development. Edward Elgar Publishing, Cheltenham, UK.

Ramirez, O.A. 2000 The carbon cycle and the value of forests as a carbon sink: a tropical case study. In: Dore, M. and Guevara, R. (eds.) Human dimensions of sustainable forest management and global climate change, 111-156. Edward Elgar Publishing, Cheltenham, UK.

Richards, M., Palmer, C., Young, C.F., and Obidzinski, K. 2003 Higher international standards or rentseeking race to the bottom? The impacts of forest trade liberalisation of forest governance. Report prepared for the Food and Agriculture Organisation (FAO) and the International Institute for Environment and Development (IIED). Project GCP/INT/775/JPN. 
Suramenggala, I., Sutisna, I.H., Saragih, I.B., Samsu, Ngau, Y. (2001) Evaluasi dampak IPPK terdahap fisik hutan, pendapaten masyarakat dan permerintah kabupatan bulungan. Yayasan Pionir Bulungan, East Kalimantan, Indonesia.

Wollenberg, E., and Kartodihardjo, H. 2002 Devolution and Indonesia's new forestry law. In: Colfer, C.J.P. and Resosudarmo, P. (eds.) Which way forward?
People, forests, and policymaking in Indonesia, 81109. Resources for the Future, Center for International Forestry Research (CIFOR) and the Institute for Southeast Asian Studies (ISEAS).

Yasmi, Y. 2003 Understanding conflict in the comanagement of forests: the case of Bulungan Research Forest. International Forestry Review 5(1): 38-44. 


\section{Appendix}

\section{IPPK permits issued by Bulungan Forestry Office, August 1999-February 2003}

\begin{tabular}{|c|c|c|c|c|}
\hline Village & Company & Size (ha) & Date IPPK issued & HPH area \\
\hline Sekatak Buji & $\begin{array}{l}\text { CV Raya Bhakti } \\
\text { CV Surya Ramadhan } \\
\text { CV Surya Ramadhan } \\
\text { CV Surya Ramadhan }\end{array}$ & $\begin{array}{r}500 \\
2,000 \\
1,300 \\
900\end{array}$ & $\begin{array}{l}21 / 09 / 1999 \\
29 / 12 / 2000 \\
22 / 08 / 2002(\text { Ext I) } \\
24 / 03 / 2003 \text { (Ext II) }\end{array}$ & $\begin{array}{l}\text { Inhutani I } \\
\text { Inhutani I } \\
\text { unknown } \\
\text { unknown }\end{array}$ \\
\hline Turung & $\begin{array}{l}\text { CV Gunung Agung Lestari } \\
\text { CV Gunung Agung Lestari } \\
\text { CV Sengon Agung Jaya Pratama } \\
\text { CV Gunung Agung Lestari } \\
\text { CV Sengon Agung Jaya Pratama }\end{array}$ & $\begin{array}{l}600 \\
375 \\
600 \\
250 \\
550\end{array}$ & $\begin{array}{l}29 / 12 / 2000 \\
20 / 08 / 2002 \text { (Ext I) } \\
20 / 08 / 2002 \text { (Ext I) } \\
24 / 03 / 2003 \text { (Ext II) } \\
24 / 03 / 2003 \text { (Ext II) }\end{array}$ & $\begin{array}{l}\text { Intracawood } \\
\text { unknown } \\
\text { unknown } \\
\text { unknown } \\
\text { unknown }\end{array}$ \\
\hline Pungit & $\begin{array}{l}\text { CV Wana Prima Mandiri } \\
\text { CV Wana Prima Mandiri } \\
\text { CV Wana Prima Mandiri } \\
\text { CV Wana Prima Mandiri } \\
\text { CV Wana Prima Mandiri }\end{array}$ & $\begin{array}{r}525 \\
700 \\
1,000 \\
280 \\
94\end{array}$ & $\begin{array}{l}22 / 10 / 1999 \\
09 / 10 / 2000 \\
21 / 12 / 2000 \\
21 / 08 / 2002 \text { (Ext I) } \\
24 / 03 / 2003 \text { (Ext II) }\end{array}$ & $\begin{array}{l}\text { Inhutani I } \\
\text { Inhutani I } \\
\text { Intracawood } \\
\text { unknown } \\
\text { unknown }\end{array}$ \\
\hline Pentian & $\begin{array}{l}\text { CV Wana Prima Mandiri } \\
\text { CV Wana Prima Mandiri } \\
\text { CV Wana Prima Mandiri } \\
\text { CV Wana Prima Mandiri } \\
\text { CV Wana Prima Mandiri }\end{array}$ & $\begin{array}{r}450 \\
500 \\
1,000 \\
\text { N/A } \\
167\end{array}$ & $\begin{array}{l}22 / 10 / 1999 \\
09 / 10 / 2000 \\
21 / 12 / 2000 \\
19 / 08 / 2002 \text { (Ext I) } \\
24 / 03 / 2003 \text { (Ext II) }\end{array}$ & $\begin{array}{l}\text { Inhutani I } \\
\text { Inhutani I } \\
\text { Intracawood } \\
\text { unknown } \\
\text { unknown }\end{array}$ \\
\hline $\begin{array}{l}\text { Keriting/ } \\
\text { Anjar Arif }\end{array}$ & $\begin{array}{l}\text { CV Malino Jaya Sekatak } \\
\text { CV Malino Jaya Sekatak } \\
\text { CV Malino Jaya Sekatak }\end{array}$ & $\begin{array}{l}500 \\
200 \\
200\end{array}$ & $\begin{array}{l}16 / 08 / 2000 \\
22 / 08 / 2002 \text { (Ext I) } \\
24 / 03 / 2003 \text { (Ext II) }\end{array}$ & $\begin{array}{l}\text { Inhutani I } \\
\text { unknown } \\
\text { Inhutani I }\end{array}$ \\
\hline Ambalat & $\begin{array}{l}\text { CV Rizky Putri Melati } \\
\text { CV Rizky Putri Melati } \\
\text { CV Rizky Putri Melati }\end{array}$ & $\begin{array}{r}1,200 \\
799 \\
799\end{array}$ & $\begin{array}{l}09 / 11 / 2000 \\
22 / 08 / 2002 \text { (Ext I) } \\
24 / 03 / 2003 \text { (Ext II) }\end{array}$ & $\begin{array}{l}\text { Inhutani I } \\
\text { unknown } \\
\text { Inhutani I }\end{array}$ \\
\hline Maritam & $\begin{array}{l}\text { CV Gunung Agung Lestari } \\
\text { CV Gunung Agung Lestari } \\
\text { CV Gunung Agung Lestari }\end{array}$ & $\begin{array}{l}600 \\
600 \\
600\end{array}$ & $\begin{array}{l}13 / 11 / 2000 \\
20 / 08 / 2002 \text { (Ext I) } \\
24 / 03 / 2003 \text { (Ext II) }\end{array}$ & $\begin{array}{l}\text { Inhutani I } \\
\text { unknown } \\
\text { unknown }\end{array}$ \\
\hline Kendari & $\begin{array}{l}\text { CV Wana Prima Mandiri } \\
\text { CV Wana Prima Mandiri } \\
\text { CV Wana Prima Mandiri }\end{array}$ & $\begin{array}{r}1,000 \\
495 \\
293\end{array}$ & $\begin{array}{l}21 / 12 / 2000 \\
21 / 08 / 2002 \text { (Ext I) } \\
24 / 03 / 2003 \text { (Ext II) }\end{array}$ & $\begin{array}{l}\text { Intracawood } \\
\text { unknown } \\
\text { unknown }\end{array}$ \\
\hline Sekatak & CV Mutiara Utama & 400 & $16 / 08 / 1999$ & Inhutani I \\
\hline Bengala & CV Mutiara Utama & 500 & $30 / 08 / 2000$ & $\begin{array}{l}\text { PT. Abindo } \\
\text { Butani Lestari }\end{array}$ \\
\hline Kelising & CV Raya Bhakti & 500 & $17 / 07 / 2000$ & Inhutani I \\
\hline Ujang & CV Kayan Lestari & 800 & $13 / 11 / 2000$ & Inhutani I \\
\hline Tenggiling & CV Kayan Lestari & 800 & $13 / 11 / 2000$ & Inhutani I \\
\hline Bekiliu & CV Sengon Agung Jaya Pratama & 1,000 & $21 / 12 / 2000$ & Intracawood \\
\hline Bunau Jalai & CV Wana Prima Mandiri & 1,000 & $21 / 12 / 2000$ & Intracawood \\
\hline Kelincauan & CV Wana Prima Mandiri & 1,000 & $21 / 12 / 2000$ & Intracawood \\
\hline Terindak & CV Wana Prima Mandiri & 1,000 & $21 / 12 / 2000$ & Intracawood \\
\hline Bambang & CV Kayan Lestari & 600 & $29 / 12 / 2000$ & Intracawood \\
\hline Punan Dulau & PT Bakti Bumi Perdana & 1,500 & $29 / 12 / 2000$ & Inhutani I \\
\hline Buong Baru & CV Sengon Agung Jaya Pratama & 844 & $24 / 12 / 2003$ & unknown \\
\hline
\end{tabular}

Source: Cabang Dinas Kehutanan (CDK) Bulungan Selatan $(1999,2000)$ and Forestry Office, Tanjung Selor, Kabupaten Bulungan, Kalimantan Timur (2003).

Notes: For permits issued in 2002 and 2003, the locations of concession areas are unknown.

'Ext I' denotes a first extension to the IPPK permit and 'Ext II' denotes a second extension. 


\section{Related CIFOR publications}

Case Study 1. McCarthy, J.F. 2001. Decentralisation, local communities and forest management in Barito Selatan District, Central Kalimantan. Center for International Forestry Research, Bogor, Indonesia.

Case Study 2. McCarthy, J.F. 2001. Decentralisation and forest management in Kapuas District, Central Kalimantan. Center for International Forestry Research, Bogor, Indonesia.

Case Study 3. Barr, C., Wollenberg, E., Limberg, G., Anau, N., Iwan, R., Sudana, I.M., Moeliono, M., and Djogo, T. 2001. The Impacts of decentralisation on forests and forest-dependent communities in Malinau District, East Kalimantan. Center for International Forestry Research, Bogor, Indonesia.

Case Study 4. Casson, A. 2001. Decentralisation of policymaking and administration of policies affecting forests and estate crops in Kutai Barat District, East Kalimantan. Center for International Forestry Research, Bogor, Indonesia.

Case Study 5. Casson, A. 2001. Decentralisation of policymaking and administration of policies affecting forests and estate crops in Kotawaringin Timur District. Central Kalimantan. Center for International Forestry Research, Bogor, Indonesia.

Case Studies 6 and 7. Potter, L. and Badcock, S. 2001. The effects of Indonesia's decentralisation on forests and estate crops: Case study of Riau province, the original districts of Kampar and Indragiri Hulu. Center for International Forestry Research, Bogor, Indonesia.

Case Study 8. Soetarto, E., Sitorus, M.T.F. and Napiri, Y. 2001. Decentralisation of administration, policy making and forest management in West Kalimantan. Center for International Forestry Research, Bogor, Indonesia.

Case Study 9. Obidzinski, K. and Barr, C. 2002. The effects of decentralisation on forests and forest Industries in Berau District, East Kalimantan. Center for International Forestry Research, Bogor, Indonesia.

\section{Others}

Anau, N., Iwan, R., van Heist, M., Limberg, G., Sudana, M. and Wollenberg, E. 2002. Negotiating More than Boundaries: Conflict, Power and Agreement Building in the Demarcation of Village Borders in Malinau, 131156. In: Technical Report Phase I 1997-2001. ITTO Project PD 12/97 Rev.1 (F) Forest, Science and Sustainability: The Bulungan Model Forest. Center for International Forestry Research, Bogor, Indonesia.

Casson, A. and Obidzinski, K. 2002. From New Order to Regional Autonomy: Shifting Dynamics of Illegal Logging in Kalimantan, Indonesia. World Development 30(12):2133-51.

Resosudarmo, I.A.P. 2003. Shifting Power to the Periphery: The Impact of Decentralisation on Forests and Forest People. In: Aspinall, E. and Fealy, G. (eds.) Local Power and Politics in Indonesia: Decentralisation and Democratisation, 230-244. Singapore, Institute of Southeast Asian Studies.

Oka, N.P. and William, D. 2004. The Policy Dilemma for Balancing Reforestation Funds. Decentralisation Brief. No. 1. Center for International Forestry Research, Bogor, Indonesia.

Colfer, C.J.P. and Resosudarmo, I.A.P. (eds). 2002. Which Way Forward: People, Forests and Policymaking in Indonesia. Washington, Resources for the Future. 
